\title{
Application of Molecular Methods in Aquaculture and Fishery
}

\author{
Zorka Dulić, Božidar Rašković, Saša Marić, Tone-Kari \\ Knutsdatter Østbye
}

\begin{abstract}
Early aquaculture studies were mainly engaged in practising different culturing systems, primarily focusing on the improvement of fish growth and feed type. The significant advances in molecular biology during the last century greatly influenced the development of genetic research and application of molecular methods in aquaculture and fishery. These methods provided substantial opportunity for increased production efficiency, better product quality and improvement of animal health. Additionally, DNA based methods provided tremendous improvement in species determination, family tracking, pedigree determination of individuals, identification of lineages, identification of markers and loci that are responsible for economically important traits. In this work we pay special attention to the utilization of restriction fragment length polymorphism (RFLP) in aquaculture and fishery as a practical and relatively cheap method for determination of genetic lineages in polymorphic fish species. We also focus on gene expression as an excellent method for understanding physiological processes in fish. Currently, quantitative real-time PCR is one of the most accurate methods for gene expression analysis. It is very precise, sensitive
\end{abstract}

How to cite this book chapter:

Dulić, Z., Rašković, B., Marić, S. and Østbye, TK., K. 2019. Application of Molecular Methods in Aquaculture and Fishery. In: Vucelić Radović, B., Lazić, D. and Nikšić, M. (eds.) Application of Molecular Methods and Raman Microscopy/ Spectroscopy in Agricultural Sciences and Food Technology, Pp. 119-139. London: Ubiquity Press. DOI: https://doi.org/10.5334/bbj.h. License: CC-BY 4.0 
and gives relatively fast results. The growing knowledge in this area has enabled better understanding of fish physiology in aquaculture aiming to achieve economical feasibility and sustainability at the same time.

\section{Introduction}

Identification of fish species is traditionally based on external morphological characters as body shape, colour, scale size, position and size of fins as well as relative size of different body parts (Strauss \& Bond 1990).

In species that are morphologically more similar number of gill rakers can be used as a significant systematic character. Furthermore, morphology of otoliths is also used in determination of fish age and size, but is especially useful for identification of the fish species from fossil remains or gut content of a predator (Granadeiro \& Silva 2000).

However, in some cases the external morphology is not sufficient for the identification and determination even with whole specimens, either due to considerable intraspecific variations or small interspecific differences (Teletchea 2009). In addition, identification of fish species using morphology is not possible when specimens are semi degraded caused by digestion, when coming from the gut content or due to processing (e.g. canning or filleting). Identification of early life stages, as eggs or larvae, is more complicated that identification of adult stages. Due to all these difficulties, researchers were looking for new methods that would provide easier and more reliable identification of fish species.

Increased fish and seafood consumption worldwide caused Intensification of international trade and consequently varying levels of supply and demand of certain high quality fish or seafood species. Development of the fish market also led to economic fraud and the substitution of one species (usually more expensive) with another fish species or seafood product (less expensive). This was particularly successful when processed fish and seafood were used as fillets or canned products (Rasmunsen et al. 2008). Thus, it has become more and more important to know valuable facts about the products on the market and the authentication of fish and seafood species an important issue. In Europe, a law has been established for fish and aquaculture products requiring traceability information as identity and origin of fish as well as production method (Regulation (EC) No 104/2000).

Traditional and official methods for the identification of different species, including fish, have been based on the separation or characterization of specific proteins using techniques as electrophoresis, liquid and gas chromatography or utilization of immunological assays (ELISA) (Moretti et al. 2003, Kvasnicka 2005, Hubalkova et al. 2007). Although these methods are valuable in species identification, especially on fresh and frozen products, they are less reliable on products that are heat processed or dried, mainly due to the biochemical 
destruction of proteins. Therefore, these methods are not practical for routine sample analysis since proteins are quite unstable after the animal death, they are thermolabile and additionally, they are variable depending on the tissue type, age and status of specimen.

During the $20^{\text {th }}$ century, as an alternative to protein analysis, DNA based methods for species identification have been developed. The advantages of DNA based methods are in the better resistance and theromostablility of the DNA molecule compared to proteins, and by using the polymerase chain reaction (PCR) small fragments of DNA can be amplified providing sufficient information for species identification (Lenstra 2003). Additionally, DNA can be recovered from almost any substrate, since it is present in all cells of an organism. Due to the development of molecular biology, identification of fish species is possible from most tissues including muscles, fins or blood.

There are a few molecular techniques that have been mostly used during the past decade for fish identification as RFLP (restriction fragment length polymorphism), PCR sequencing (known also as FINS - forensically informative nucleotide sequencing) and PCR specific primers. More recently, two methods have developed, real-time PCR and microarray, both used in gene expression research as well as in species identification (Teletchea 2009).

In fish breeding programs, DNA based methods are used for family tracking, pedigree determination of individuals, identification of lineages, identification of markers and loci that are responsible for economically important traits as growth, survivorship, sexual maturity, disease resistance, deformities and nutrient utilization (Davis \& Hetzel 2000).

\subsection{Application of Restriction fragment length polymorphism (RFLP) in aquaculture and fishery}

RFLP is a quite simple, robust and relatively cheaper method (Aranishi 2005). It is based on the polymorphisms in the lengths of particular restriction fragments of the geneticcode (Rasmunsen et al. 2008). The target genes are amplified with PCR and then cut by specific endonucleases on a few smaller fragments, different in size, that are used for identification of fish lineages or species (Liu \& Cordes 2004). Different fragments are separated by agarose gel electrophoresis. The gel is then exposed to UV light and with the gel documentation system (transluminator) is photographed. The lengths of the fragments are measured by using the DNA standard (ladder).

This method is particularly useful for the identification of genetic distance between different populations of a species coming from a wider geographic region. It is of key importance that the fish populations under research are highly polymorphic, meaning that they have not been frequently crossbred.

For identification of low polymorphic fish population, other methods mentioned above, or microsatellites are used. 


\subsection{Application of real-time PCR ( $q P C R)$ in aquaculture}

A significant part of research in fishery and aquaculture focuses on gene expression as an excellent method for understanding physiological processes in aquatic animals, mainly fish (Overturf 2009). Evaluation of genes that play significant roles in different biological processes as embryonic and adult growth, efficiency in nutrient utilization, disease resistance and other are used in many research programs in fishery and aquaculture (Nilsen \& Pavey 2010). Provided by numerous investigations, the growing knowledge in this area has enabled better understanding of fish physiology in aquaculture aiming to achieve economical feasibility and sustainability at the same time.

Quantitative real-time PCR (qPCR) is one of the most accurate methods for gene expression analysis. It is very precise, sensitive, shows good reproducibility, as well as relatively fast results (Derveaux et al. 2010). Although this method is quite easy to use, it is very important to maintain a high level of quality control throughout the entire process. Imprecision in the protocol application can significantly influence the accuracy of results and affect the credibility of research conclusions.

Traditional end-point PCR provides only information on the presence or absence of a specific genetic product, while the advantage of quantitative realtime PCR (qPCR) is in the measurement of the number of copies and the detection of small differences between samples during the reaction.

In real-time $\mathrm{qPCR}$, the detection of PCR products is provided by the presence of a fluorescent dye that binds to the double stranded DNA. The registered amount of fluorescence signal in the qPCR machine responds to the amount of amplified product during every amplification cycle. The most commonly used fluorescent dye that binds to the DNA molecule is SYBR Green I. This nonspecific dye binds to the double stranded DNA molecule whose fluorescence intensity in increased up to 1000 times during the binding. Ct or threshold cycle is the value showing the number of amplification cycles during which the fluorescent signal reaches the threshold level (level above the background fluorescence). Lower number of cycles i. e. Ct values lower $<29$ shows higher amount of the product.

The relative gene expression method is based on the differences in the level of expression in target genes (gene of interest) compared to one or several reference genes (genes whose expression is not affected by the applied treatment) (Pfaffl 2006). To identify the reference gene it first has to be checked how is it expressed. There are several on line programs to evaluate which gene is best to use as reference, e.g. http://fulxie.0fees.us/. The Ct values of the gene are added and the program calculates the most stable gene.

For calculating the gene expression there are different mathematical models. One that is frequently used is the delta delta $\mathrm{Ct}$ method:

$2^{\wedge}(-\mathrm{ddCt})$, where $\mathrm{ddCt}=(\mathrm{Ct}$ target gen treated - Ctreference gen treated $)-$ (Ct control target gen- Ct control reference gen) 
Aquacarp laboratory equipment:

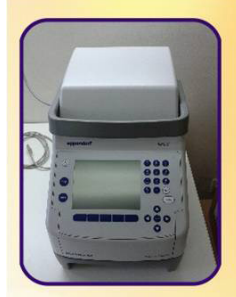

Eppendorf

Mastercycler proS

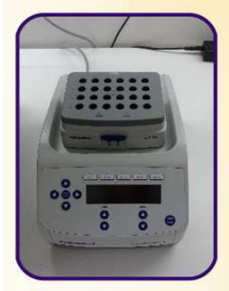

Eppendorf

ThermoStat C

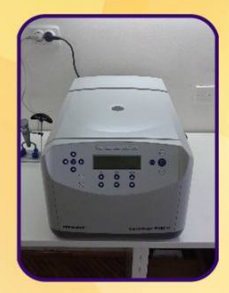

Eppendorf

Centrifuge $5430 \mathrm{R}$

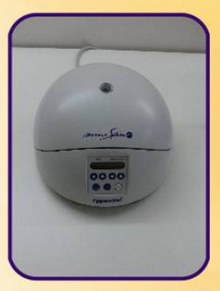

Eppendorf

MiniSpin Plus

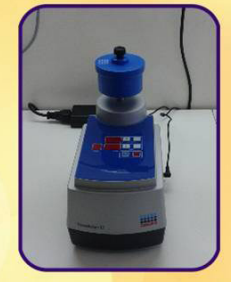

QIAGEN

Tissuelyser LT

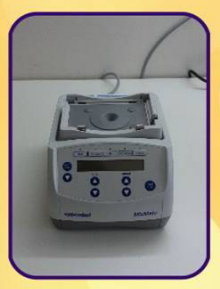

Eppendorf

MixMate

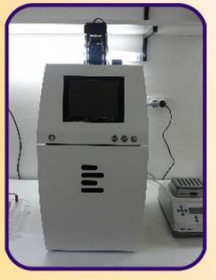

Vilber Lourmat Transilluminator

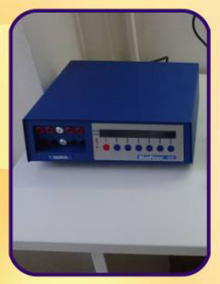

Serva

Electrophoresis system

\section{Materials, Methods and Notes}

\subsection{Determination of genetic lineages of highly polymorphic fish species, Brown trout (Salmo trutta), by PCR-RFLP-based analysis}

In this method two genes were tested, one nuclear (gene for lactate dehydrogenase) and one mitochondrial gene (gene for the control region of the mitochondrial DNA).

\subsubsection{DNA isolation}

For DNA extraction, a commercial kit (ZR Genomic DNA ${ }^{\mathrm{m}}$-Tissue MiniPrep Kit, Zymo Research, Irvine, USA) was used and following procedure is listed according to manufacturer's instruction:

- $25 \mathrm{mg}$ of fish fin is placed in eppendorf tube of $1.5 \mathrm{ml}$

- Add to every tube:

$\mathrm{H} 2 \mathrm{O} 95 \mu \mathrm{l}$

2X Digestion Buffer $95 \mu \mathrm{l}$

Proteinase K $10 \mu \mathrm{l}$ 
- Vortex the mix and incubate in the thermostat at $55^{\circ} \mathrm{C} 1$ do 3 hours (optionally it can stay during thenight). One hour after the incubation shake the tube a couple of times to allow proper digestionof the fin.

- After the incubation period, add $700 \mu$ l Genomic Lysis Buffer and vortex the mix thoroughly. Centrifugeat $10,000 \times \mathrm{g} 1 \mathrm{~min}$ to eliminate the cell debris ( $1 \mathrm{~g}=1 \mathrm{RCF})$.

- Put the Spin Column (Zymo-Spin ${ }^{\mathrm{TN}}$ IIC Column) into a $2 \mathrm{ml}$ eppendorf tube without a cap (collection tube)

- Transfer the supernatant into the Spin Column. Centrifuge at 10,000 × g 1 min (DNA binding to themembrane).

- Transfer to a new collection tube and add $200 \mu$ DNA Pre-Wash Buffer. Centrifuge at 10,000 x g $1 \mathrm{~min}$ (DNA I washing).

- Add $400 \mu \mathrm{l}$ g-DNA Wash Buffer into the column. Centrifuge at 10,000 $\times \mathrm{g}$ 1 min (DNA II washing).

- Transfer to a new column, a regular clean $1.5 \mathrm{ml}$ eppendorf tube with a cap. Add $\geq 50 \mu \mathrm{l}$ DNA ElutionBuffer or Milli-Q water (e.g. if $25 \mathrm{mg}$ of fin tissue is used add $200 \mu \mathrm{l}$ of liquid) in the spin column.

- Incubate for 2-5 $\mathrm{min}$. at room temperature than centrifuge at maximal speed for 30 seconds to eluate the DNA.

Eluated DNA can be used immediately or can be kept at $\leq-20^{\circ} \mathrm{C}$ and used later. If the isolated DNA will be used in the next few weeks, it can be kept in the refrigerator.

\subsubsection{Primer selection}

For CRmtDNA gene 28RIBa and CytR primers were used and for LDH gene Ldhxon3F and Ldhxon4F (Table 1). These primers were selected since they proved to be very useful in distinguishing trout of Atlantic and Danubian lineages in previous studies (McMeel et al. 2001, Maric et al. 2010).

Primers are received in lyophilized form. They should be dissolved with MilliQ water adding $10 \mathrm{x} \mu \mathrm{l}$ more water into the total number of primer nmol: e.g. primer 28RIBa has in total $31.6 \mathrm{nmol}$, it should be added $31.6 \times 10 \mu \mathrm{l}=316 \mu \mathrm{l}$ water

\begin{tabular}{|l|l|l|}
\hline \multicolumn{1}{|c|}{ Primer name } & \multicolumn{1}{c|}{ Sequence } & \multicolumn{1}{c|}{ Gene } \\
\hline Ldhxon3F & GGCAGCCTCTTCCTCAAAACGCCCAA & LDH \\
\hline Ldhxon4R & CAACCTGCTCTCTCCCTCCTGCTGACGAA & LDH \\
\hline 28Riba & CACCCTTAACTCCCAAAGCTAAG & CR mtDNA \\
\hline CytR & GTGTTATGCTTTAGTTAAGC & CR mtDNA \\
\hline
\end{tabular}

Table 1: Primers and their sequences used in the study (T.-K. Knutsdatter Østbye). 
The working primer solution is made by dissolving the solution $10 \mathrm{x}(10 \mu \mathrm{l}$ of solution and $90 \mu \mathrm{l}$ of water is added into the ependorf tube). Both solutions are kept in the freezer.

\subsubsection{PCR-RFLP protocol for control region of mRNA and nuclear gene coding for lactate dehydrogenase}

For the PCR reaction, first the PCR Mix should be made. All the reagents, except Taq polymerase, should be taken out of the freezer and warmed up at room temperature. While waiting for the warm up of reagents, put the eppendorf tubes $(0.2 \mathrm{ml})$ in the cooling stand and add $1 \mu \mathrm{l}$ of eluated DNK into every tube. Number of PCR tubes depend on the number of fish samples (10 fish - 10 PCR eppendorf tubes). The PCR mix is made in one eppendorf tube of $1.5 \mathrm{ml}$ kept in the cooling stand.

The amount for 10 reactions is (if less or more reaction done, this amount should be recalculated):

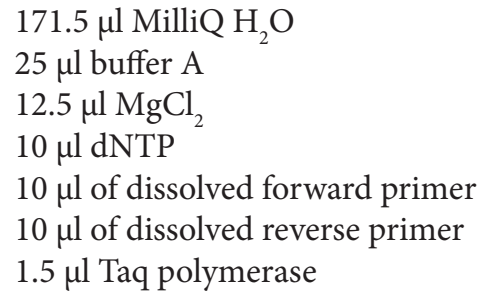

Polymerase is added at the end, very quickly, taking care that it doesn't stay too long at room temperature. Vortex the Mix and add into every PCR eppendorf tube $24 \mu \mathrm{l}$ :

$1 \mu \mathrm{l} \mathrm{DNK}+24 \mu \mathrm{l}$ Mix-a

The Mix should always be made for one more reaction than the number of samples, to have enough in case something goes wrong e. g. if we analyze DNA of 10 fish, the mix should be made for 11 fish. The PCR eppendorf tubes are kept in the cooling stand. If it starts changing colour, a new cooling stand from the freezer should be taken and tubes transferred to it. Switch on the cycler and wait until the cover reaches $100^{\circ} \mathrm{C}$, and then quickly transfer the tubes from the cooling stand into the cycler.

The conditions of the cycler are adopted depending on the gene analyzed.

For the entire controlregion of mitochondrial DNA (CR mtDNA) (1088 bp) the conditions are:

1. step: $94^{\circ} \mathrm{C}-3 \mathrm{~min}$

2. step: $94^{\circ} \mathrm{C}-45 \sec ^{*}$

3. step : $54^{\circ} \mathrm{C}-45 \sec ^{\star}$

4. step: $72^{\circ} \mathrm{C}-1 \min 20 \sec ^{*}$ 
5. step: $72^{\circ} \mathrm{C}-10 \mathrm{~min}$

6. step: $10^{\circ} \mathrm{C}-\infty$

*** steps 2-4 are repeated 32 times

For the nuclear gene coding for lactate dehydrogenase (LDH) (428 bp), the conditions are:

1. step: $94^{\circ} \mathrm{C}-3 \mathrm{~min}$

2. step: $94^{\circ} \mathrm{C}-45 \mathrm{sec}^{*}$

3. step: $62^{\circ} \mathrm{C}-45 \sec ^{*}$

4. step: $72^{\circ} \mathrm{C}-1 \min ^{*}$

5. step: $72^{\circ} \mathrm{C}-10 \mathrm{~min}$

6. step: $10^{\circ} \mathrm{C}-\infty$

*** steps 2-4 are repeated 32 times

After the program is finished the PCR product is kept in the refrigerator for a few weeks. If the product should be kept for longer it should be put it the freezer.

\subsubsection{Separation of the $\mathrm{LDH}$ and CR $\mathrm{mtDNA}$ restriction fragment}

Before the gel electrophoresis, the agarose gel should be made, cast into the gel tray, and the buffer added. The buffer is an electrolyte that allows the electric current flow.

\section{Preparation of $1.5 \%$ agarose gel}

The total amount of gel that should be made is $140-150 \mathrm{ml}$.

For $140 \mathrm{ml}$ :

- measure $210 \mathrm{~g}$ of agarose on the analytical balance in a small beaker.

- Transfer the agarose into the Erlenmeyer flask.

- Add $140 \mathrm{ml}$ TBE x0.5 buffer.

- Put the flask into the microwave and cover it with a Petri dish.

- Switch on the maximal hear and let it boil

- When it starts boiling switch off the microwave and shake the agarose so it can dissolve completely. Than let it boil for 10 more seconds.

- When the solution cools down a bit, so it stays liquid, cast it into the tray with the combs (well former templates) and dams (rubber end caps) already in position.

- Wait until the gel cools down and carefully take out the combs. 


\title{
Preparation of TBE x 5 buffer
}

\author{
Tris $54.48 \mathrm{~g}$ \\ Boric acid $27 \mathrm{~g}$ \\ EDTA $10 \mathrm{ml} 0.5 \mathrm{M}$ solution \\ Distillate water up to $1000 \mathrm{ml}$
}

Put Tris into a small volume of distillate water and mix well. Add Boric acid and mix. These two substances easily mix. Make the the EDTA buffer I and keep it in the refrigerator in a volumetric flask. TBE $\mathrm{x} 5$ buffer is made by $10 \mathrm{x}$ dilution (mix $100 \mathrm{ml}$ TBE x 5 buffer and add $900 \mathrm{ml}$ of distillate water). TBE $\mathrm{x} 0.5$ buffer can be kept at room temperature until it is used up.

Note: Take care not to put the pH electrode into Tris, because it will destroy it.

\section{Preparation of sample buffer}

Buffer blue is used as a carrier for loading the sample on the gel:

Distilled water $1 \mathrm{ml}$

Glycerol $0.5 \mathrm{ml}$

A very small amount of Bromophenol Blue (enough to stain the solution)

The mixture separates into two phases, glycerol and water, but after vortexing the mix for $20 \mathrm{~min}$ the phases will integrate. The colour of the solution can vary from red (if the $\mathrm{pH}$ is low) to blue (if the solution is neutral or higher than 7). The solution should be vortexed every time before using it. Keep it in dark at room temperature.

After the gel cools down transfer it with the tray into the electrophoresis apparatus chamber, take off the rubber end caps and add TBE $x 0.5$ buffer to cover the gel. Cut a piece of parafilm and place 5-20 $\mu \mathrm{l}$ of sample on it (eluated DNA, PCR product or product of restriction-more details at Fig. 1) in droplets, separated by $2-3 \mathrm{~cm}$ from one another. Next to the sample droplets, $5 \mu \mathrm{l}$ of DNA standard (ladder) should be placed. Into every sample droplet 0.5 $\mu \mathrm{l}$ Midori green is added, except into the ladder where $1 \mu \mathrm{l}$ of Midori green is added. After this, into every droplet 2-3 $\mu$ of Buffer Blue is added. Then the parafilm with sampes (droplets) is transferred to the gel and added into every well. Mark the wells. The ladder is added in the first or last well. Adapt the electrical current to be constantly $120 \mathrm{~V}$.

\subsubsection{Gel documentation}

Switch on the apparatus (Transilluminator) for taking a picture of the gel and click on the button „Live“. Enter the USB into the port that is on the right side 
of the apparatus. Stop the electrical current 45-60 minutes after the electrophoresis, raise the cover and pour out the buffer. The tray with the gel is transferred near the apparatus. Gel is then moved on to the transluminator surface by opening the apparatus door and sliding out the surface so that the transfer of the gel is easier. Gel should be laid smoothly with no air bubbles present under the gel. Push the transluminator surface back into the apparatus, close the door and switch on the UV light (button for UV light). Sometime the gel slides backward so it is advisable to put a piece of plastic underneath. Adjust the contrast and intensity pressing the buttons „" “ or „-“ " until the sufficient quality is reached. Adjust the zoom and focus on the objective manually (objective is positioned on the top of the apparatus). Take a picture of the gel by pressing the button "freeze“. If the USB in in the apparatus, the picture will automatically be saved in the folder "Images" on the USB (Fig. 1.). If the folder doesn't exist, the apparatus will automatically create it, and if the USB is not inserted, the picture will be saved in the internal memory of the apparatus. The gel should be photographed immediately, since after few hours, DNA will become invisible.

Digestion results are visible on Fig.1. On the left side of the DNA ladder the restriction digestof 4 fish sampes (A4, A5, P4, P5) were done with the SatI

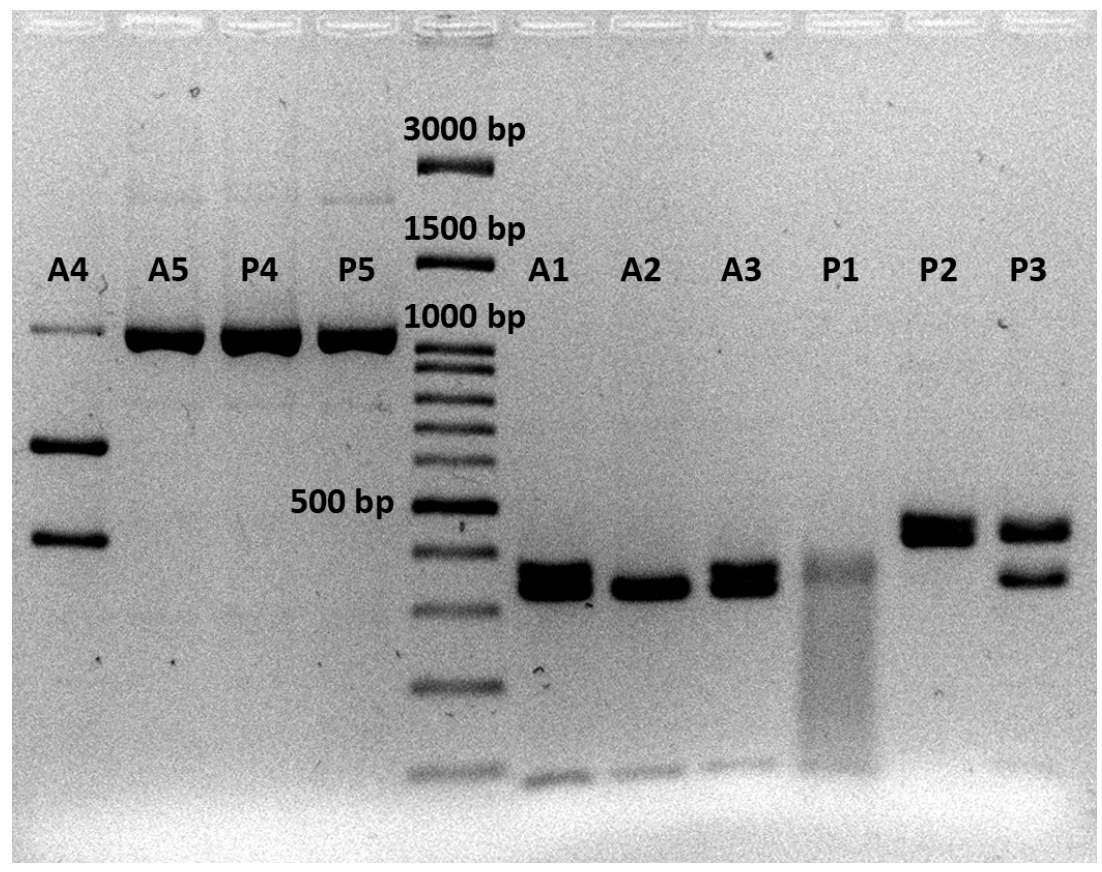

Figure 1: The gel with obtained restriction fragments of brown trout genes after RFLP assay. 
enzyme of the control region on the mtDNK (1088 bp). Control region of Danubian lineage remains uncutwhile Atlantic (At) lineage is cut into two fragments (654 and 434bp). On the right of DNA ladder, the restriction digestof 6 fish samples (A1-A3 and P1-P3) is done with the BseLI endonucleasesfor the gene for lactate dehydrogenase ( $428 \mathrm{bp}$ ). Danubian lineage remains uncut whileLDH gene of Atlantic lineage is cut into two fragments (353and $75 \mathrm{bp}$; fragments of $75 \mathrm{bp}$ were too small to be visible on gels).

\subsection{Expression of the genes in intestines of Atlantic salmon (Salmo salar) after various feeding treatments, detected by reverse transcription (RT) qPCR method}

The expression of selected genes was investigated in the intestines of salmon (Salmo salar) fed different levels of n-3 fatty acids i. e. eicosapentaenoic acid (EPA) and docosahexaenoic acid (DHA) throughout life. These selected genes are involved in EPA and DHA synthesis, fatty acid oxidation, and synthesis of prostaglandins and immunity.

\subsubsection{Sample preparation}

Fish were reared in cages and fed pre-diets (5 different types of diets) in the period from 4 to $400 \mathrm{~g}$. During the later period fish from $400 \mathrm{~g}$ to $4 \mathrm{~kg}$ were fed main diets (3 types). Fish intestines were sampled from the $4 \mathrm{~kg}$ group and stored at $-80^{\circ} \mathrm{C}$ prior toanalysis. Intestines from six specimens per treatment were selected for the analysis. In total 84 samples.

\subsubsection{Total RNA extraction}

For Total RNA extraction, a commercial kit (PureLink ${ }^{\mathrm{TM}} 96$ Pro 96 Total RNA Purification Kit, Invitrogen, USA) was used and following procedure is listed according to manufacturer's instruction:

- Add $1 \mathrm{~mL}$ TRIzol ${ }^{\mathrm{TM}}$ Reagent (Invitrogen) to $2 \mathrm{~mL}$ tubes for Precyllis 24 with 2-3 beads.

- Add approximately $20 \mathrm{mg}$ tissue.

- Homogenize the sample in Precyllis24 in centrifuge at $5500 \mathrm{rpm} 2 \times 20 \mathrm{sec}-$ onds.

At this point samples are processed in batches, in case there is a lot of samples e.g. 24 samples (depending on the type of refrigerated centrifuge) can be further processed while rest have to be stored at $-80^{\circ} \mathrm{C}$, and processed within a month. 


\subsubsection{Trizol protocol:}

- Incubate the homogenized sample for 5 minutes at room temperature to permit the completedissociation of the nucleoprotein complexes.

- Add $0.2 \mathrm{ml}$ of chloroform per $1 \mathrm{ml}$ of Trizol Reagent. Cap sample tubes securely.

- Shake tubes vigorously by hand for 15 seconds.

- Incubate the samples at room temperature for 2 to 3 minutes.

- Centrifuge the samples at no more than $12,000 \times \mathrm{g}$ for 15 minutes in the refrigerated centrifuge at $4^{\circ} \mathrm{C}$ (Fig.2 right).

Following centrifugation, the mixture separates into a lower red, phenolchloroform phase, an interphase, and a colourless upper aqueous phase. RNA remains exclusively in the aqueous phase. The volume of the aqueous phase is about $60 \%$ of the volume of Trizol Reagentused for homogenization (Fig.2 left).

\subsubsection{Transfer of samples to PureLink ${ }^{\mathrm{TM}} 96$ Well Total RNA Filter Plates}

- Transfer $350 \mathrm{uL}$ the colourless upper aqueous phase to new tubes. Add 1× volume of PureLink Pro96 Lysis Buffer, $350 \mathrm{uL}$.

- Add a volume of $100 \%$ ethanol equal to the aqueous phase;x. $350 \mathrm{uL}$.

- Mix well.

- Place the PureLink ${ }^{\mathrm{TM}} 96$ Well Total RNA Filter Plate on top of a PureLink ${ }^{\mathrm{TM}}$ 96 Receiver Plate. Transfer samples to the PureLink ${ }^{\mathrm{TM}}$ Well Total RNA Filter Plate (Fig.3).

- Seal the plates with a cover.

- Centrifuge the stacked plates at $\geq 2,100 \times$ g for $1-2$ minutes at room temperature.

Note: If some of the samples did not go through the columns, remove the cover and spin 1 minute at $2,100 \times g$.
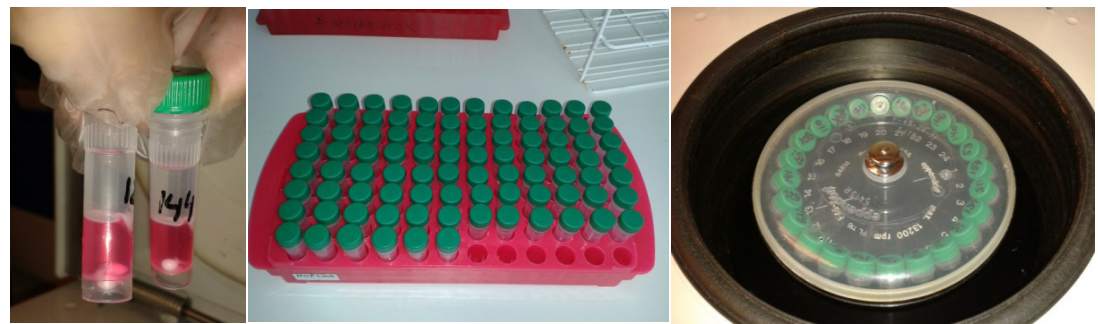

Figure 2: Left-tubes with separated phases, middle - preparation of tubes for tissue homogenization, right - 24 tubes in refrigerated centrifuge. 

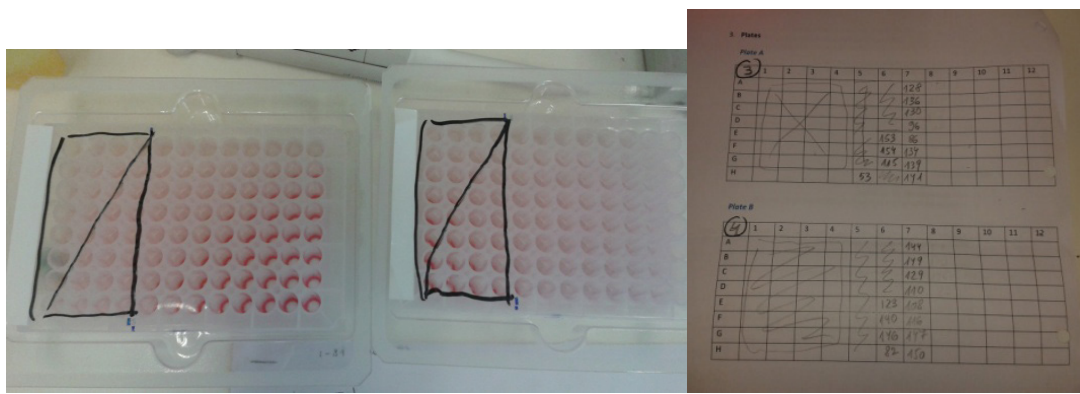

Figure 3: Left - marked PureLink ${ }^{\mathrm{TM}} 96$ Well Total RNA Filter Plates, right samples numbers marked in the tables indicating which will be used in the PureLink $^{\mathrm{TM}} 96$ Well Total RNA Filter Plates.

\begin{tabular}{|l|l|l|l|l|}
\hline & $\mathbf{1 0 0} \times \mathbf{:}$ & $\mathbf{1} \times \mathbf{:}$ & \multicolumn{1}{|c|}{$\mathbf{1 6 \times :}$} & \multicolumn{1}{|c|}{$\mathbf{2 6 \times :}$} \\
\hline $10 \times$ DNase I buffer & $0,8 \mathrm{ml}$ & $8 \mu \mathrm{l}$ & $128 \mu \mathrm{l}$ & $208 \mu \mathrm{l}$ \\
\hline DNase I & $2700 \mathrm{U}$ & $9,9 \mu \mathrm{l}$ & $158 \mu \mathrm{l}$ & $257.4 \mu \mathrm{l}$ \\
\hline RNase-free water & to $8 \mathrm{ml}$ & $62 \mu \mathrm{l}$ & $992 \mu \mathrm{l}$ & $1612 \mu \mathrm{l}$ \\
\hline
\end{tabular}

Table 2: Amount of DNase reagents for digestion, right highlighted column shows the amount for 26 samples.

- Discard flow-through from the PureLink ${ }^{\mathrm{TM}}$ Receiver Plate and place the PureLink ${ }^{\mathrm{TM}}$ RNA Filter Plateon top of the PureLink ${ }^{\mathrm{TM}}$ Receiver Plate.

\subsubsection{On-Column DNase Digestion:}

For On-Column DNase Digestion a commercial kit (PureLink ${ }^{\mathrm{TM}} 96$ DNase for use with PureLink ${ }^{\mathrm{TM}}$ Kits, On-Column Protocol Only, Invitrogen, USA) was used and following procedure is listed according to manufacturer's instruction:

Prepare DNase solution depending on the number of samples, e.g. if you have 24 samples always add reagents for two more reactions (Table 2).

Note: Make the DNAse solution in a bigger eppendnof tube and keep it on ice until used.

- Add $500 \mathrm{uL}$ wash buffer I to each sample. Centrifuge at $2100 \mathrm{xg}$ for 2 minutes.

- Add 80uL DNase solution to each sample.

- Incubate for 15 minutes at room temperature 


\subsubsection{Buffer washing}

- Add $500 \mathrm{uL}$ wash buffer I and incubate for 5 minutes

- Centrifuge at $2100 \mathrm{xg}$ for 2 minutes, discard flow-through.

- Add $750 \mathrm{uL}$ wash buffer II - Centrifuge at $2100 \mathrm{xg}$ for 2 minutes, discard flow-through.

- Add 750 uL wash buffer II

- Centrifuge at $2100 \mathrm{xg}$ for 2 minutes, discard flow-through.

- Dry the plate by centrifugation at $2100 \mathrm{xg}$ for 10 minutes.

Note: Buffer II should be prepared freshly before adding to the samples. Buffer II needs to be diluted 1:5 with 95-100\% ethanol; $24 \times 750 \mathrm{uL} \times 2$ (washes) $=36 \mathrm{ml}$ ( $8 \mathrm{ml}$ of $5 \times$ buffer II $+32 \mathrm{ml}$ of $96 \%$ ethanol)

\subsubsection{RNA Eluation}

- Place the filter plate on top of a new PureLink ${ }^{\mathrm{TM}}$ Pro 96 Eluation Plate (Fig. 4 left).

- Add approximately $60 \mathrm{uL}$ RNase free water (regularly add 45uL, but more can be added, depending on the type of tissue).

- Incubate for 1 minute at room temperature.

- Centrifuge at $2100 \mathrm{xg}$ for 2 minutes to eluate RNA.

- Transfer eluated RNA to tubes. Work on ice.

- Measure concentration and quality of RNA of every sample with the Nanodrop (Fig.4 right).

- Store the RNA samples at $-80^{\circ} \mathrm{C}$.

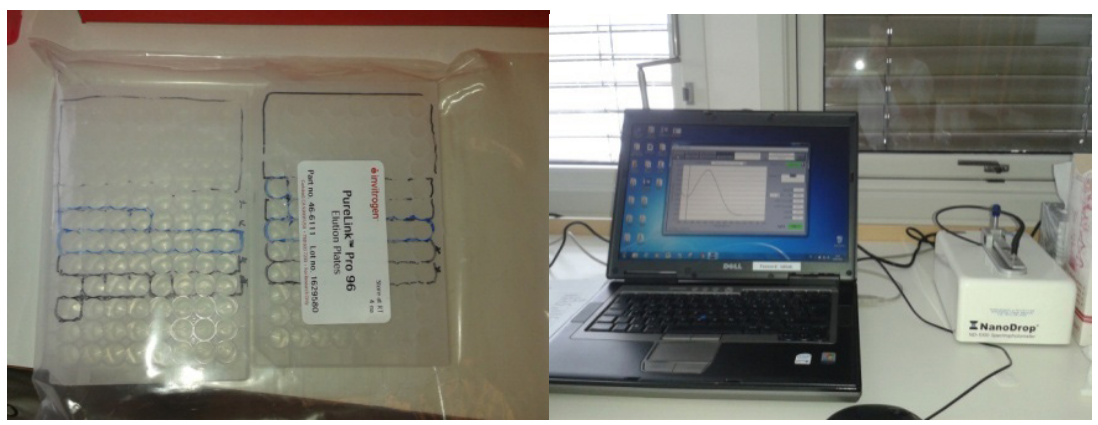

Figure 4: Left PureLink ${ }^{\mathrm{TM}}$ Pro Eluation Plates with marked wells that will be used, right Nanodrop spectrophotometer connected to the computer program. 


\subsubsection{TaqMan qPCR Assay: cDNA synthesis and specific gene amplification}

For cDNA synthesis and expression of selected genes TaqMan Reverse Transcription Reagents (Applied Biosystems) with SYBR ${ }^{\mathrm{mm}}$ Green (LightCycler ${ }^{\circ}$ 480SYBRGreen Master I) dye method for labelling and detecting qPCR products was used.

cDNA was made from $1000 \mathrm{ng}$ of RNA. According to the concentration of RNA received from the Nanodrop, calculation is made for every sample by dividing 1000 with the RNA concentration e.g. 1000/536.2=1.80 $\mu \mathrm{L}$ RNA. In order to calculate the amount of RNA free water that that should be added to every sample, the $\mu \mathrm{L}$ of RNA is subtracted from 7.7 (e.g. 7.7-1.8 $=5.8 \mu \mathrm{L}$ of RNA free water) for a $20 \mu \mathrm{L}$ TaqMan reaction (Table 3).

For calculating the amount of Taqman regents for the total number of samples, the number of samples (84) is multiplied with the amount of every TaqMan reagent (Table 3, right). Than the volume of TaqMan reagent per one

\begin{tabular}{|l|l|l|l|}
\hline \multicolumn{1}{|c|}{$\begin{array}{c}\text { Taqman cDNA } \\
\text { synthesis }\end{array}$} & \multicolumn{1}{|c|}{$\begin{array}{c}\text { Number of } \\
\text { samples }\end{array}$} \\
\hline $\begin{array}{l}\text { TaqMan }{ }^{\oplus} \text { Reverse } \\
\text { Transcription Reagents }\end{array}$ & stock conc. & $\begin{array}{l}20 \text { uL reaction } \\
(\mathrm{uL})\end{array}$ & 84 \\
\hline $10 \mathrm{x}$ TaqMan ${ }^{\otimes}$ RT Buffer & $10 \times$ & 2 & 168 \\
\hline $25 \mathrm{mM} \mathrm{MgCl}{ }_{2}$ & $25 \mathrm{mM}$ & 4.4 & 369.6 \\
\hline $10 \mathrm{mM} \mathrm{dNTP} \mathrm{mixture}$ & $10 \mathrm{mM}$ & 4 & 336 \\
\hline Oligo d(T) ${ }_{16,50 \mathrm{um}}$ & $50 \mathrm{uM}$ & 1 & 84 \\
\hline RNase Inhibitor & $20 \mathrm{U} / \mathrm{ul}$ & 0.4 & 33.6 \\
\hline $\begin{array}{l}\text { Reverse Transcriptase } \\
(50 \mathrm{U} / \mu \mathrm{l})\end{array}$ & $50 \mathrm{U} / \mathrm{ul}$ & 0.5 & 42 \\
\hline RNA $250-1000 \mathrm{ng}$ & & $\mathrm{x}$ & $\Sigma 1033.2$ \\
\hline Rnase free water & & 7.7 & \\
\hline Total & & 20 & \\
\hline
\end{tabular}

Table 3: $\mathrm{TaqMan}^{\circ}$ Reverse Transcription Reagents and calculation of the amount for the $20 \mathrm{uL}$ reaction, right column amount of TaqMan reagents for 84 samples.

Note: The first 4 reagens from the table should be kept on ice before using them, while the Rnase inhibitor and Reverse Transcriptase are kept frozen before using. 
sample is calculated by dividing the total volume of reagents for all samples with the number of samples (e. g. 1033.2/84=12.3 $\mu \mathrm{L}$ ).

Samples are transferred to a new type of plated and RNA free water and $12.3 \mu \mathrm{L}$ per sample of Taqman mixture is added. In one well a mixture of RNA samples without enzymes is added to check for the presence of genomic DNA (NTC - non template control) (Table 4. up).

After adding all the parts, the plate are shortly centrifuged ( 1 min on $2000 \mathrm{~g}$ ), and placed in the PCR machine. The reaction conditions should be $25^{\circ} \mathrm{C}$ for 10 $\min , 48^{\circ} \mathrm{C}$ for $60 \mathrm{~min}$ and $95^{\circ} \mathrm{C}$ for $5 \mathrm{~min}$

After the amplification, $180 \mu \mathrm{L}$ of RNA free water is added to every sample. Then from every sample $10 \mu \mathrm{L}$ is taken and transferred into one eppendorfer tube to make the "cDNA mix". The "cDNA mix" is used for making a standard curve later.

Next step is transferring the samples from the main plate to the master plates (1 and 2) (Table 4. up). Half and half of samples (42) are transferred to the master plates 1 and 2. During this every sample was duplicated (Table 4, qPCR master plate 1 and master 2).

Using the microdispenser machine, from every master plate, 15 white LightCycler per master plate were copied (in total 30 plates). After this process, every sample contains $4 \mu \mathrm{L}$ of cDNA.

Note: Always make more copies than number of primers analyzed. (e.g. if 13 primers are analysed, 10 target genes and 3 referent genes, a few more copies are made - 15 plates per master plate, in total 30 new plates (Fig.5).

Every plate is covered with a special sealing cover, centrifuged for $1 \mathrm{~min}$ at $2000 \mathrm{rpm}$, and stored at -20 until used.

Next step is adding chosen primers and SybrGreen fluorescent dye to every sample before placing them into the qPCR machine.

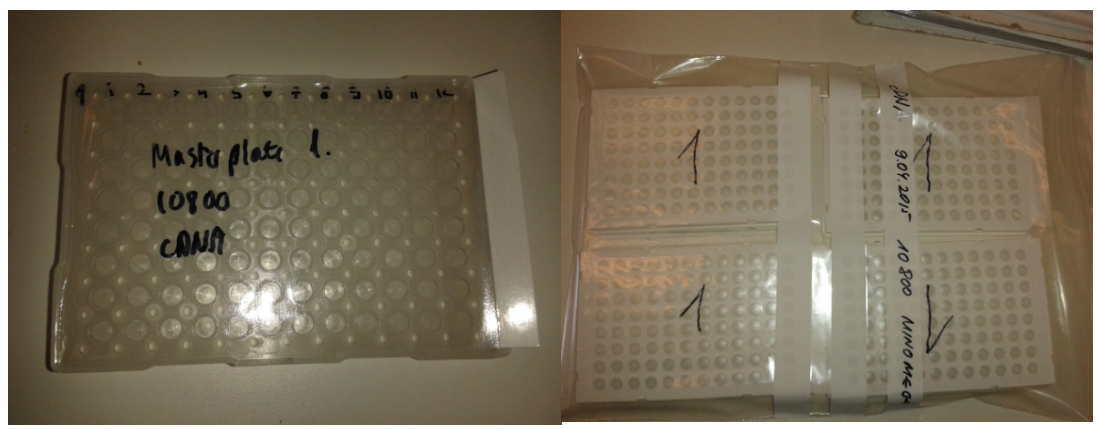

Figure 5: Left master plate 1, right 15 copies of master plate. 
cDNA synthesis

\begin{tabular}{|c|c|c|c|c|c|c|c|c|c|c|c|c|}
\hline & 1 & 2 & 3 & 4 & 5 & 6 & 7 & 8 & 9 & 10 & 11 & 12 \\
\hline A & 1 & 3 & 7 & 8 & 9 & 10 & 11 & 13 & 14 & 16 & 20 & 23 \\
\hline B & 25 & 26 & 27 & 28 & 29 & 30 & 33 & 40 & 43 & 45 & 62 & 72 \\
\hline C & 153 & 86 & 144 & 136 & 128 & 149 & 141 & 108 & 147 & 116 & 82 & 130 \\
\hline D & 128 & 154 & 134 & 140 & 123 & 115 & 139 & 96 & 150 & 110 & 53 & 146 \\
\hline E & 182 & 80 & 163 & 124 & 212 & 88 & 183 & 91 & 159 & 173 & 180 & 221 \\
\hline F & 175 & 170 & 107 & 185 & 122 & 145 & 111 & 168 & 118 & 174 & 169 & 165 \\
\hline G & 54 & 117 & 77 & 126 & 102 & 160 & 161 & 90 & NTC & & & \\
\hline H & & & & & & & & & & & & \\
\hline
\end{tabular}

qPCR masterplate 1

\begin{tabular}{|c|c|c|c|c|c|c|c|c|c|c|c|c|}
\hline & 1 & 2 & 3 & 4 & 5 & 6 & 7 & 8 & 9 & 10 & 11 & 12 \\
\hline A & 1 & 1 & 3 & 3 & 7 & 7 & 8 & 8 & 9 & 9 & 10 & 10 \\
\hline B & 25 & 25 & 26 & 26 & 27 & 27 & 28 & 28 & 29 & 29 & 30 & 30 \\
\hline C & 153 & 153 & 86 & 86 & 144 & 144 & 136 & 136 & 128 & 128 & 149 & 149 \\
\hline D & 128 & 128 & 154 & 154 & 134 & 134 & 140 & 140 & 123 & 123 & 115 & 115 \\
\hline E & 182 & 182 & 80 & 80 & 163 & 163 & 124 & 124 & 212 & 212 & 88 & 88 \\
\hline F & 175 & 175 & 170 & 170 & 107 & 107 & 185 & 185 & 122 & 122 & 145 & 145 \\
\hline G & 54 & 54 & 117 & 117 & 77 & 77 & 126 & 126 & 102 & 102 & 160 & 160 \\
\hline H & $\begin{array}{c}\text { cDNA } \\
\text { mix }\end{array}$ & $\begin{array}{c}\text { cDNA } \\
\text { mix }\end{array}$ & $\begin{array}{c}\text { cDNA } \\
\text { mix }\end{array}$ & & & & & & & & & \\
\hline
\end{tabular}

qPCR masterplate 2

\begin{tabular}{|c|c|c|c|c|c|c|c|c|c|c|c|c|}
\hline & 1 & 2 & 3 & 4 & 5 & 6 & 7 & 8 & 9 & 10 & 11 & 12 \\
\hline A & 11 & 11 & 13 & 13 & 14 & 14 & 16 & 16 & 20 & 20 & 23 & 23 \\
\hline B & 33 & 33 & 40 & 40 & 43 & 43 & 45 & 45 & 62 & 62 & 72 & 72 \\
\hline C & 141 & 141 & 108 & 108 & 147 & 147 & 116 & 116 & 82 & 82 & 130 & 130 \\
\hline D & 139 & 139 & 96 & 96 & 150 & 150 & 110 & 110 & 53 & 53 & 146 & 146 \\
\hline E & 183 & 183 & 91 & 91 & 159 & 159 & 173 & 173 & 180 & 180 & 221 & 221 \\
\hline F & 111 & 111 & 168 & 168 & 118 & 118 & 174 & 174 & 169 & 169 & 165 & 165 \\
\hline G & 161 & 161 & 90 & 90 & NTC & NTC & & & & & & \\
\hline H & $\begin{array}{c}\text { cDNA } \\
\text { mix }\end{array}$ & $\begin{array}{c}\text { cDNA } \\
\text { mix }\end{array}$ & $\begin{array}{c}\text { cDNA } \\
\text { mix }\end{array}$ & & & & & & & & & \\
\hline
\end{tabular}

Table 4: Upper table, main plate used for making the two master plates (qPCR masterplate 1 i 2 ), middle and lower table. 
For the qPCR reaction mix use:

$0.5 \mu \mathrm{L}$ reverse primer

$0.5 \mu \mathrm{L}$ forward primer

$5 \mu \mathrm{L}$ Sybrgreen dye

$4 \mu \mathrm{L}$ cDNA (amount in every sample)

Diluted primers are kept in the freezer. Defrost1-2 minutes at room temperature before use. Initially, primers are delivered in lyophilized form and are dissolved with RNA free water. The amount of primer needed should be calculated according to the total number of reactions. If 96 well plates (96 samples) are used than $0.5 \mu \mathrm{L} \times 96=48 \times 2$ (if there is two master plates) $=96 \mu \mathrm{L}$ of primer. Into this, $10 \times$ more RNase free water is added $-960 \mu \mathrm{L}$.

Selected target genes were ACO, COX1, COX2, d5d, d6fad_a, d6fad_b, Elovl2, Elovl5b, nrf, nfkb. Referent gene were: etif and Ef1a (Table 5).

Every primer is made in a separate eppendorf tube marked at the beginning (e.g. COX1 r and COX1 f) (Fig.6).

Dissolved primers are kept on ice before transferring to the samples. SybrGreen is kept in the freezer until the package is opened. An open package is saved in the fridge until it's used up. It should be used within one week. The amount of SybrGreen is calculated for the total number of reactions $5 \mu \mathrm{L} \times$ $96=480 \mu \mathrm{L}$.

Into every sample $6 \mu \mathrm{L}$ of dissolved primer and Sybrgreen reagent is added preferably using the multistep pipette, especially when having plates with 96 or more wells. The plates are sealed with a special type of translucent protective foil for qPCR (LightCycler sealing foil) and centrifuged $1 \mathrm{~min}$ at $2000 \mathrm{rpm}$. The plates are then placed in the LightCycler (qPCR machine) and runned using the chosen type of program (Fig. 7).

The qPCR reaction was run on a LightCycler ${ }^{\mathrm{rm}} 480$ (Roche Diagnostics Gmbh, Germany) under the following conditions: Preincubation at $95^{\circ} \mathrm{C}$ for $5 \mathrm{~min}$ utes, amplification with 45 cycles at $95^{\circ} \mathrm{C}$ for 15 seconds and $60^{\circ} \mathrm{C}$ for 1 minutes, melting curve at $95^{\circ} \mathrm{C}$ for 5 seconds and $65^{\circ} \mathrm{C}$ for 1 minutes, cooling at $40^{\circ} \mathrm{C}$ for 10 seconds.

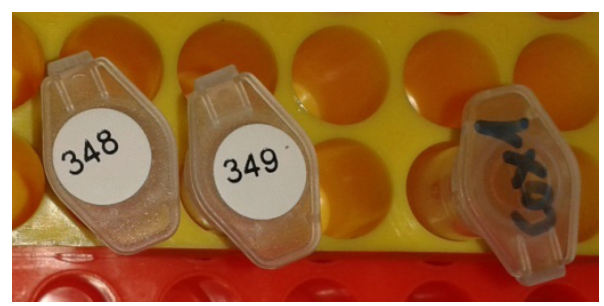

Figure 6: Left reverse and forward primer COX1 (marked with register numebrs), right marked eppendorf tube for dissolved primer COX $1 \mathrm{r}$. 


\begin{tabular}{|l|l|}
\hline \multicolumn{1}{|c|}{ Primer name } & \multicolumn{1}{c|}{ Sequence } \\
\hline Ssa elong 2F1 & CGGGTACAAAATGTGCTGGT \\
\hline Ssa elong 2 R1 & TCTGTTTGCCGATAGCCATT \\
\hline Ssa ACO F1 & CCTTCATTGTACCTCTCCGCA \\
\hline Ssa ACO R1 & CATTTCAACCTCATCAAAGCCAA \\
\hline Ssa d5d F2 & GCTTGAGCCCGATGGAGG \\
\hline Ssa d5d R2 & CAAGATGGAATGCGGAAAATG \\
\hline Ssa d6d A F3 & TCCCCAGACGTTTGTGTCAGATGC \\
\hline Ssa d6d A R3 & GCTTTGGATCCCCCATTAGTTCCTG \\
\hline Ssa d6d B/C R2 & CACAAACGTCTAGGAAATGTCC \\
\hline Ssa d6d B F3 & TGACCATGTGGAGAGTGAGGG \\
\hline Ssa d6d B R3 & AACTTTTGTAGTACGTGATTCCAGCT \\
\hline Ssa d6d C F2 & TGAAGAAAGGCATCATTGATGTTG \\
\hline Ssa EF1a F & CACCACCGGCCATCTGATCTACAA \\
\hline Ssa EF1a R & TCAGCAGCCTCCTTCTCGAACTTC \\
\hline Ssa etif3 F1 & CAGGATGTTGTTGCTGGATGGG \\
\hline Ssa Etif3 R1 & ACCCAACTGGGCAGGTCAAGA \\
\hline Ssa nrf F2 & CCGGACTCCTCGCCTTCGGA \\
\hline Ssa nrf R2 & GTGGATAGTTGGCTTGTCCCTTCGT \\
\hline Ssa nfkb F1 & CAGCGTCCTACCAGGCTAAAGAGAT \\
\hline Ssa nfkb R1 & GCTGTTCGATCCATCCGCACTAT \\
\hline Ssa Elovl5b F2 2 GCAACCTTGACCCAAACAGG \\
\hline Ssa Elovl5b R2 & CCTTGTCTCTACGCAAGGGA \\
\hline Ssa cox2 F2 & CCCCCGACTTACAATGCTGA \\
\hline Ssa cox2 R2 & GCGGTTCCCATAGGTGTAGG \\
\hline & \\
\hline
\end{tabular}

Table 5: The primers and sequences used in the study (T.-K. Knutsdatter Østbye).
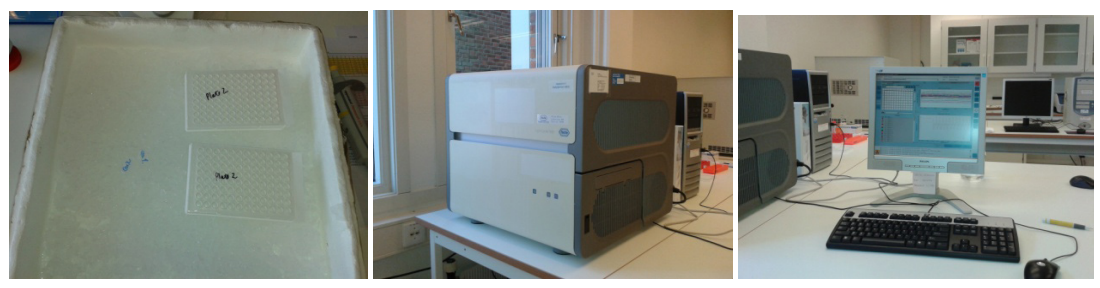

Figure 7: Left - plates ready for adding the primers and SybrGreen-a, middle Roche $^{\text {Tm }}$ LightCycler $^{\text {TM }} 480$, right - monitoring the process of amplification on the LightCycler computer program. 
Note: Be careful while putting the solution in the wells, since this small volume, can jump out of the well. Best is to bring the pipette tip next to the wall lower in the well, but not touching. If a droplet "jumps" out of the well, take it a away with a ordinary pipette and tip, and add once more a droplet from the multistep pipette. Take a note on the exact sample where we made a mistake.

After all plates are runned in the qPCR machine, the data for Ct values for all reactions are taken from the LyghtCycler software (can be transfered to excel) and are further processed using chosen mathematical model for relative gene expression.

\section{Acknowledgements}

This work was funded by EU Commission project AREA, no. 316004. These analyses are a part of an ongoing project at Nofima, National food Institute in Norway, As, at the Biotechnology laboratory. We are grateful to Bente Ruyter, Tone-Kari Knutsdatter Østbye and Marta Bou Mira for providing samples and tremendous help during the analyses.

\section{References}

Aranishi, F. (2005). Rapid PCR-RFLP method for discrimination of imported and domestic mackerel. Marine Biotechnology, 7(6), 571-575. DOI: https:// doi.org/10.1016/j.aquaculture.2004.05.027

Davis, G. P., \& Hetzel, D. G. (2000). Integrating molecular genetic technology with traditional approaches for genetic improvement in aquaculture species. Aquaculture Research, 31, 3-10. DOI: https://doi.org/10.1046/j.13652109.2000.00438.x

Derveaux, S., Vandesompele, J., \& Hellemans, J. (2010). How to do successful gene expression analysis using real-time PCR. Methods, 50, 227-230. DOI: https://doi.org/10.1016/j.ymeth.2009.11.001

Granadeiro, J. P., \& Silva, M. A. (2000). The use of otoliths and vertebraein the identification and size-estimation of fish inpredator-prey studies. Cybium, 24, 383-393.

Hubalkova. Z., Kralik, P., Tremlova, B., \& Rencova, E. (2007). Methods of gadoid fish species identification in food and their economicimpact in the Czech Republic: a review. Veterinarni Medicina, 52,273-292.

Kvasnicka, F. (2005). Capillary electrophoresis in food authenticity. Journal of Separation Science, 28,813-825, DOI: https://doi.org/10.1002/ jssc. 200500054

Lenstra, J. A. (2003). DNA methods for identifying plant and animal species in food. In: M.Lees (Ed.), Food authenticity and traceability (pp. 34-53). Cambridge, U.K.,Woodhead Publishing Ltd. 
Liu, ZJ., \& Cordes, J. F. (2004). DNA marker technologies and their applications in aquaculture genetics. Aquaculture, 238(1-4), 1-37.

Marić, S., Simonović, P., \& Razpet, A. (2010). Genetic characterization of broodstock brown troutfrom Bled fish-farm, Slovenia. Periodicum Biologorum, 112,145-148. ISSN 0031-5362

McMeel, M. O., HOEY, M. E., \& Ferguson, A. (2001). Partial nucleotide sequences, and routine typing by polymerase chain reaction-restriction fragment length polymorphism, of the brown trout (Salmo trutta) lactate dehydrogenase, LDH-C1 ${ }^{\star} 90$ and ${ }^{\star} 100$ alleles. Molecular Ecology, 10, 29-34. DOI: https://doi.org/10.1046/j.1365-294X.2001.01166.x

Nielsen, J. L. \& Pavey, S. A. (2010). Perspectives: Gene expression in fisheries management. Current Zoology. 56(1), 157-174.

Overturf, K. (2009) Quantitive PCR. In K. Overturf (Ed.), Molecular Research in Aquaculture (pp 39-56), Wiley-Blackwell, Oxford, UK. DOI: https://doi. org/10.1002/9780813807379

Pfaffl, M. W. (2006). Relative quantification. In T. Dorak (Ed.) Real-time PCR (pp. 63-82). Taylor \& Francis Group.

Rasmussen, R. S., \& Morrissey, M. T. (2008). DNA-Based Methods for the Identification of Commercial Fish and Seafood Species. Comprehensive reviews in food science and food safety, 7, 280-295. DOI: https://doi.org/10.1111/ j.1541-4337.2008.00046.x

Strauss, R. E. \& Bond, C. E. (1990). Taxonomic methods: morphology. In C.B. Schreck, P.B. Moyle (Eds.) Methods for fish biology (pp. 109-140). American Fisheries Society, Maryland.

Teletchea, F. (2009). Molecular identification methods of fish species: reassessment and possible applications. Reviews in Fish Biology and Fisheries, 19, 265-293. DOI: https://doi.org/10.1007/s11160-009-9107-4

\section{Useful links to the topics of this chapter:}

http://www.gene-quantification.com/real-time-pcr-handbook-life-technologies-update-flr.pdf

http://www.bio-rad.com/webroot/web/pdf/lsr/literature/Bulletin_5279.pdf

http://www.gene-quantification.info/

http://fulxie.0fees.us/

http://eur-lex.europa.eu/legal-content/EN/TXT/?uri=URISERV\%3Al66002 
